\title{
List of figures, maps, and tables
}

\section{Figures}

10.1 News print on the capture of Belgrade by the Holy League in 1688 . Romeyn de Hooghe, Belgrado met syn slot en voor-steden stormenderhand verovert door de keyserlyke machten. Den 6 sept: 1688. 1688. $46.6 \mathrm{~cm} \times 58.1 \mathrm{~cm}$. Rijksmuseum Amsterdam RP-P-OB-67.735.

10.2 Detail of news print on the fall of Belgrade. Romeyn de Hooghe, Belgrado met syn slot en voor-steden stormenderhand verovert door de keyserlyke machten. Den 6 sept: $1688.1688 .46 .6 \mathrm{~cm} \times 58.1 \mathrm{~cm}$.

Rijksmuseum Amsterdam RP-P-OB-67.735.

10.3 Detail of news print on the capture of Buda by the Holy League in 1686. Romeyn de Hooghe, Belegering der sterke stad Buda of Offen, door de Keyserlycke en geallieerde machten. 1686. 1686. Noord-Hollands Archief, collection Voorhelm Schneevoogt, NL-HlmNHA_53009097_o1 NL-HlmNHA_53009097_02.

10.4 Detail of news print on the fall of Belgrade. Romeyn de Hooghe, Belgrado met syn slot en voor-steden stormenderhand verovert door de keyserlyke machten. Den 6 sept: $1688.1688 .46 .6 \mathrm{~cm} \times 58.1 \mathrm{~cm}$. Rijksmuseum Amsterdam RP-P-OB-67.735.

10.5 Fictive triumphal entry of Leopold I to celebrate the Holy League's capture of Buda. Romeyn de Hooghe, Divo et invictissimo Leopoldo $I[\ldots]$. 1686-87. Rijksmuseum Amsterdam RP-P-1930-231.

10.6 Satirical print on the events of the year 1687. Romeyn de Hooghe, Koning-Spel Courant op 't Jaer 1687, Amsterdam 1687-88. Rijksmuseum Amsterdam RP-P-OB-76.963. 
10.7 Detail of Figure 10.6. Dunnewald impales an Ottoman soldier on his spear.

10.8 Detail of Figure 10.6. On the left, Janković before a hearth with roasted Turkish heads and limbs. On the right, the dwarf servant of the sultan's cook dropping his food in the ashes of the hearth.

\section{Maps}

7.1 Trade routes between Moscow and Caffa in the 1470s-1570s.

13.1 Pasturage requirement for one year for one tümen of Mongolian warriors, at twenty-six sheep-equivalents per man.

13.2 Cherokee town clusters as they were c.1715.

13.3 Cherokee towns as of about 1760 . Each cross indicates a town site that had existed in 1715 . The thick line approximates the amount of territory abandoned by the Cherokees.

\section{Tables}

13.1 Conquest types in war between sedentary agricultural states

13.2 'Conquest' types in war between steppe tribes

13.3 'Conquest' types in war between Eastern Woodlands Native Americans 